\title{
Research on Comparison of Goodwill Accounting between China and Western Countries
}

\author{
Xiang Lin \\ Beijing Jiaotong University, Beijing 100044, China \\ lixiang@163.com
}

Keywords: Goodwill accounting, Comparison between China and western countries.

\begin{abstract}
With the coming of knowledge economy era, intangible asset makes up a growing percentage of enterprise assets, and has become the main component of assets such as Microsoft Company. As the most intangible asset, goodwill accounting plays an increasing role in operation and management of enterprises. With the deepening of economic system reform, especially with the emergence of enterprise mergers and acquisitions, the accountants have to face goodwill. Because goodwill is special and complicated, how to confirm, measure, record and report it scientifically is the research focus and difficulty in accounting field, and many scholars propose different views and opinions from different perspectives. However, the theoretical divergence will make the practice lack of unified standard. Under the situation, it has great significance for specifying and unifying accounting practice, and improving accounting information quality to enhance the research and exploration on the theory of goodwill accounting.
\end{abstract}

\section{Comparison of Goodwill Accounting Theory between China and Western Countries}

Theory of excess earnings in China. In theory of excess earnings, goodwill means the ability of enterprises achieving the profits greater than the normal profitability. In business combination, the purchasing price of the purchasing enterprises is higher than the fair value of the achieved net asset, the reason for which is that the net asset which is predicted to be achieved is greater than the normal profit, which means that there is goodwill. American scholars point out if an enterprise has superior profitability, which means that the enterprise has the capacity to achieve the profit greater than the normal or representative return, and the profitability is not confirmed by the specialized rights such as patent or exclusivity, the enterprise is considered to have goodwill or the general intangible value.

Theory of surplus value in England. In order to remedy the defect of excess earnings concept that it is difficult to be measured accurately, some scholars proposed the theory of surplus value or master valuation account. The scholars consider that goodwill is the balance of overall assessment value or transfer price of enterprises and future net flow discounted present value of single identifiable net assets (tangible net assets and identifiable intangible assets). George Oates point out we can't assess the net present value of a good name and reputation, an excellent staff and the relationship between society and business. Under the situation, the balance of the net present value of a subject and the net present value of the assets which can directly valuated is goodwill. The objective of an enterprise merging the other enterprise is not to purchase the single asset, but to consider that the future profitability of the other enterprises is better than the normal profitability. The part that the purchasing cost exceeds the fair value of the identifiable net asset is goodwill.

Theory of Core Goodwill in America. On September 7th, 1999, the Financial Accounting Standards Board in America published an exposure draft, and it is the first time to propose the concept of core goodwill.

FASB considers that goodwill consists of six factors. (1) The balance that the fair market value of the net assets of the acquired enterprise is greater than the book value when it is purchased. (2) The fair market value of the unconfirmed net assets of the acquired enterprises. (3) The fair market value of going-concern component of the acquired enterprises. (4) The fair market value of the expected collaborative effect for the combination of net assets and business of the acquired 
enterprises and the acquiring enterprises. (5) The more-measured amount by the acquiring enterprises because of errors. There is no measurement error for the purchasing price in all cash transaction, but once the transaction about stock exchange is concerned, it is nearly impossible that there is no measurement error. (6) The more-payed or less-payed amount by the acquiring enterprises.

\section{Comparison of Goodwill Accounting Treatment in China and Western Countries}

Comparison of goodwill accounting confirmation. Goodwill accounting confirmation method of enterprises in China

The book Accounting of the unified certified public accountant examination stipulates that goodwill relates to the enterprises, so it can't exist singly and can't be sold by separating from identifiable assets of enterprises. And it provides that goodwill can be innovative or purchased, but only the purchased is the intangible asset. Therefore, only when the enterprise purchases the other enterprise, the purchased goodwill is the intangible asset, and there is no detailed instruction for concrete treatment. The accounting regulations in the ministry of finance have detailed stipulation for the acquisition of state-owned enterprises and accounting process of goodwill. For example, the merged enterprises should evaluate the assets by the statutory asset appraisal institutions based on property verification. For the acquisition of non-state-owned enterprises, the existing regulations have no the stipulation of compulsory execution, which leaves law empty for the non-state-owned enterprises to select other methods for goodwill treatment. The result is reducing the comparability of accounting information of the enterprises with different ownership. With the emergence of enterprise acquisition, the problem is more and more outstanding.

Goodwill accounting confirmation method of enterprises in America. In the US, four standards which are suitable for all confirmations are confirmed in the fifth concept of FASB, Confirmation and Measurement of Enterprise Financial Statement, and the purchased goodwill meets the above standard. Firstly, definability. The core goodwill of the purchased goodwill meets the definition of capital. Secondly, measurability. The purchasing price provides basis for purchasing the initial measurement of goodwill and makes it possible. Thirdly, relevance. Purchasing goodwill meets the relevant confirmation standard. Lastly, reliability. According to the concept release of FASB, the information of the programs should be reliable, and the information must be verifiable and impartial. The core goodwill meets the standard of reliability. Non-core factors can't reflect faithfully, but the faithful reflection and reliable measurement of accounting is not absolute. To some extent, non-core goodwill meets the standard of reliability of accounting confirmation.

From the above comparison for confirmation and measurement of goodwill in China and western countries, we can see that the presentation is different, but the essence is the same.

Comparison of purchased goodwill. Treatment of purchased goodwill of enterprises in China.

The Instruction about Enterprise Accounting Criterion--Intangible Assets which was published by Ministry of Finance in 1995 proposes that purchasing goodwill should use the same accounting treatment method like other long-term assets.

Treatment of purchased goodwill of enterprises in western countries. In 1970, the seventeenth position paper published by APB in the US stipulates that the purchased goodwill system should be amortized according to the straight-line method, and the the longest amortization limitation should be less than 40 years according to the legal factors and advantages of enterprises. If it is greater than 40 years, it must be amortized in 40 years, and a shorter limitation can't be set artificially.

Comparison of negative goodwill treatment. Enterprise Accounting Criteria--Intangible Assets in China proposes that the balance that the price of an enterprise buying another enterprise is less than the identifiable net assets of the purchased enterprises is called negative goodwill. It is confirmed to be a liabilities of an enterprise, and it should be amortized in 5 years.

Treatment method for negative goodwill in western enterprises. FASB in America considers that negative goodwill not only is not the asset, but also is not liability. And it is named as the excess. APB17 regulates that the balance of the purchasing price and the net asset fair price of the purchased enterprise firstly should be attributed to depreciatory asset item, and the surplus balance 
is shared to non-current assets except for long-term bond and stock investment. If the balance of the non-current assets has been reduced to zero and still has balance (it is rare), the balance is amortized in 40 years as deferred income, and is credited for the profit and loss ( it is the same with the treatment method of the positive goodwill). The 22th standard accounting practice announcement published by ASC in England requires that the negative goodwill should be credited into contingency account as the increase of the stockholders equity. ASB in England considers that negative goodwill is the mirror image of positive goodwill. Positive goodwill can immediately reduce the stockholder's equity, and the negative goodwill is the increase of the equity.

ED47 which was published in 1990 remedied SSAP22, and requires to reflect negative goodwill on the asset balance sheet as a contra-asset, and credits the profit and loss during appropriate period.

Comparison for treatment method of negative goodwill. In enterprise acquisition, there are the following reason for the generation of negative goodwill. Firstly, the disadvantages of competition for the acquired enterprises are more evident. In order to make up the possible asset impairment or low earning ratio, the acquired enterprises pre-require loss compensation, which is the fundamental reason of negative goodwill. There are other reasons. For example, in the bargaining process, the acquiring enterprises may reduce the purchasing price. The paper considers that the negative goodwill with different reasons should receive accounting treatment by different methods. It is not reasonable to confirm the balance of the net assets fair value and the purchasing cost. It is not appropriate to make the accounting treatment of negative goodwill with that of positive goodwill. So the provisions which are similar to the specifications in France and China is worthy of improvement.

\section{Enlightenment of Difference of Chinese and Western Goodwill Accounting on China}

It is well-known that the generation and development of accounting and the selection of accounting process methods is influenced and restricted by the accounting environment. The present accounting environment has the following restriction factors for the confirmation, measurement, record and report of the innovative goodwill.

There is great difference between asset assessment in China and developed countries, especially the intangible assets. The theory of intangible asset assessment is not improved, and the practice of intangible asset assessment is not specified. Disordered management of evaluation influences the discounted value of excess earnings of asset assessment institutions. So it is difficult to make the value of the assessed innovative goodwill achieve the trust of the public, which directly restricts that the enterprises disclose the innovative goodwill in accounting statement as an asset.

Information gathering and release system is not imperfect. The information system in China mainly gathers and releases the information of state-owned enterprises or listed companies. The information of non-listed companies and non-state-owned enterprises is not easy to be achieved, and information delay is common, which influences the reliability of innovative goodwill measurement and selection of measurement methods. If the average capital fund profit margin and the average yield rate indicator can't be achieved, only the historical data can replace in computation. And only the industrial data of state-owned enterprises is used to replace industrial data because of lacking of the information of non-state-owned enterprises.

The quality of the accountants is low, which restricts the establishment of innovative goodwill accounting. It is represented by lower quality of accountants and deficient professional ethics quality of accounts. The writer thinks that the innovative goodwill accounting treatment in China should follow the steps below. Firstly, the listed company with greater proportion for innovative goodwill is selected as the experimental unit. The innovative goodwill receives confirmation, and the innovative goodwill value is disclosed and revealed in the appendix of accounting statement. The value measurement of innovative goodwill uses excess earnings discounted cash method, and the enterprises compute year by year. And it is affirmed by the accounting firm. Secondly, with the disappearance of restriction factors, innovative goodwill is receives balance confirmation, measurement and record in experimental units, the information is disclosed and revealed in statement, and the other enterprises can disclose the value of innovative 
goodwill in the appendix of accounting statement. Thirdly, when the conditions are matured, the innovative goodwill is confirmed, measured, recorded and disclosed in enterprise accounting statement.

\section{References}

[1] Y.J. Yang, T. Jiang. Reflections on goodwill accounting problems of. knowledge economy, 2015,05:82.

[2] S.H. Hou. Consolidated goodwill accounting issues in Enterprise Based on value to study. Inner Mongolia coal economy, 2015,02:81-82.

[3] Z.Q. Wang. International comparison of consolidation accounting treatment of goodwill accounting study of, 2015,01:30-32.

[4] J. Chen and Z.Y. Luo. Goodwill and impairment of the relevant tax processing of. accounting monthly, 2014,23:73-75.

[5] Y.H. Li. Corporate merger accounting historical changes and in the future development of our country modern. business, 2015,02:191-193.

[6] X.J. Zhou. On the goodwill accounting thoughts on. management, 2015,02:34.

[7] J.H. Zhong and J.Y. Xu. cooperation of economy and technology of negative goodwill accounting treatment problems, 2015,03:162-164.

[8] M.F. Liu. Analysis and the proposed management thinking goodwill misunderstanding, misunderstanding of crisis management behavior, 2015,05:256.

[9] Y.H. Li, Y. Zhang and H. Yang. Study on the problem of. technology horizon goodwill confirmation and measurement, 2014,33:68+71.

[10] Q. Wu. The financial accounting problems in goodwill, 2014,24:123-124. 